\title{
Response of Indonesian rice varieties to iron toxicity under field and green house condition
}

\author{
Trias Sitaresmi ${ }^{1 *}$, Katerine Dewi ${ }^{2}$, Indrastuti Apri Rumanti ${ }^{1}$, Siti Herlinda ${ }^{3}$, Yudhistira \\ Nugraha $^{4}$ \\ ${ }^{1}$ Indonesian Center for Rice Research, Jalan Raya 9 Sukamandi, Subang, West Java, Indonesia \\ ${ }^{2}$ Graduate Student of Sriwijaya University \\ ${ }^{3}$ Sriwijaya University \\ ${ }^{4}$ Indonesia Center for Food Crops Research and Development
}

\begin{abstract}
Excess of reduced iron $\left(\mathrm{Fe}^{2+}\right)$ will affect the plant growth of rice when it is grown under waterlogged condition. Some rice genotypes have been identified tolerance to iron toxicity with different mechanism-type of tolerance. This study aims to identify the response of some rice genotypes to iron toxicity, and to evaluate their consistency in the greenhouse screening method and the field condition. The experiments were conducted in iron toxicity hotspot area, Banyuasin (South Sumatera) and the control as irrigated rice field was in Sukamandi (West Java). The green house experiment of $\mathrm{Fe}$ toxicity was done using $400 \mathrm{ppm}$ of Iron with Yoshida Agar Solution method. The response of rice plant to iron toxicity was observed on leaf bronzing score (LBS), iron content and uptake, biomass, yield and yield components and stress tolerant index (STI). We found that there was not clear relationship between the iron content with the leaf bronzing symptom depending on type of tolerant while the stress tolerance index was corelated with the yield. There were two varieties was identified as tolerant, namely Cilamaya Muncul as includer tolerant genotype and Awan Kuning as the excluder tolerant genotype. The information of the distinct response those rice germplasms can be used for recommendation for further study and development of rice tolerant to iron toxicity condition.
\end{abstract}

\section{Introduction}

Rice is a semi-aquatic plant that can be grown on dry land and waterlogged conditions. Under irrigated rice farmer inundate the land from vegetative stage until maturity, to control the weeds and make condition more effective for fertilizers application. Under such conditions causes soil become anaerobic, where oxygen diffuses 10,000-fold lower in water than in the atmospheric condition [1]. The reduction of soil minerals is also enhanced by the existence of anaerobic microbes [2], converted from insoluble form of $\mathrm{Fe}^{3+}$ to soluble form and available to plants of $\mathrm{Fe}^{2+}[3]$.

Iron toxicity in rice is caused as an effect of excessive $\mathrm{Fe}^{2+}$ uptake and usually occurs at range of $1,000-2,000 \mathrm{ppm}$ of $\mathrm{Fe}^{2+}$ that may affect rice grain yield [4,5]. Iron toxicity

\footnotetext{
* Corresponding author: triassitaresmi@gmail.com
} 
interferes metabolic processes and cause damage the rice plants organs, which is marked by leaf bronzing symptoms, delayed of flowering, inhibited assimilate processes, dwarfed of plant posture, less developed of root system, decayed, roughed and shorted of stems and leaves $[6,7]$

Rice plant can develop a mechanism of avoidance or tolerance both morphologically and physiologically to survive on soil conditions with high iron solubility. Four types of plant adaptation to iron toxicity [8], such as 1) Avoidance inclusion, roots remove iron to avoid damage of shoot tissue by oxidation in the zone of rhizosphere or through mechanism of root selectivity to ion $[9,10]$, or increased $\mathrm{pH}$ of soil solution with $\mathrm{OH}$ efflux to decrease $\mathrm{Fe}^{2+}$ activity [11]; 2) Avoidance inclusion, iron absorbed by roots but damage of plant tissues may be avoided by compensation such as leaves that are not actively photosynthesized [12], or stored in cell vacuoles, iron storage proteins [13, 14]; 3) Tolerant inclusion, plant is able to tolerate iron into the shoot tissue by detoxifying enzymatically effects of iron toxicity [14, 15]; 4) Membrane selectivity through transporter protein Iron Regulated Transporter [16].

There have been reported that some Indonesian rice have tolerance to iron toxicity, i.e., Inpara 2, Inpara 3 [17]; Inpara 8, Inpara 9, Inpara 10 (Certificate of National Released Variety) however, there is still lack of study regarding mechanism response of rice genotypes to iron toxicity under the field and compared to the green house condition, especially in partitioning iron uptake in the shoot and root and its correlation to the browsing symptom. This study aims to identify response of some rice genotypes to iron toxicity, and to evaluate consistency of greenhouse screening method and field condition under the iron stress in rice plant.

\section{Methodology}

The experiment was conduct in three locations, that were tidal swamp (Telang Lago, Banyuasin) which is iron-stressed hotspot area, normal condition (Sukamandi Experimental Station), and greenhouse of Indonesian Center for Rice Research. Twenty rice genotypes consist of local varieties, swamp and irrigated varieties were used in the field and greenhouse experiment (Table 1). The field experiment was designed using randomized block design with three replications. Every genotype was planted in $7 \mathrm{~m}^{2}$ of plot size with $25 \mathrm{~cm} \mathrm{x} 25 \mathrm{~cm}$ of plant spacing. Response of plant to iron toxicity was observed on variable of leaf bronzing symptom, plant height, biomass, yield, and yield component.

The greenhouse experiment was designed using augmented design. There was two set of greenhouse experiment, which was stress condition and optimal condition. Screening method for iron toxicity using Yoshida Agar Solution with 300 ppm of $\mathrm{FeSO}_{4} \cdot 7 \mathrm{H}_{2} \mathrm{O}$ [18]. The leaf bronzing score (LBS) were determined using scoring index scale, based on bronzing symptoms in leaves [19] at the fifth and tenth days after $\mathrm{Fe}^{2+}$ treatments. The relative yield performance of genotypes in iron stressed and non-stressed environment can be used as an indicator to identify tolerant genotypes. A stress tolerance index was defined as [20]:

$$
S T I=\frac{\left(\left(Y_{i}\right)_{N S} X\left(Y_{i}\right)_{S}\right)}{Y_{N S}^{2}}
$$

STI $=$ stress tolerant index, $\mathrm{Y}_{\mathrm{i}} \mathrm{NS}=$ yield under normal condition, $\mathrm{Y}_{\mathrm{i}} \mathrm{S}=$ yield under stress condition. This formula can be used to identified genotypes that produce high yield under both stress and non-stress environment. High value of STI indicate high tolerance of stress. The genotype has STI value higher relatively than others was indicate more tolerant.

Fe content analysis to explain whether iron was accumulated in the body of rice plant. Iron should be translocated from rhizosphere by the root and should be allocated through xylem into the grain [20]. Tolerance-typed to iron toxicity can be categorized into two types 
namely, exclusion and inclusion tolerance-type. This identification can be done simply by checking the presence of $\mathrm{Fe}^{2+}$ in the shoots and root of rice plant [21-23]. Shoot and root iron content, and iron uptake was analyzed using wet destruction with $\mathrm{HNO}_{3}$ and $\mathrm{HClO}_{4}$ (methods). Sample of shoot and root were harvested in vegetative phase. As much as $0.25 \mathrm{~g}$ of sample $+2.5 \mathrm{ml} \mathrm{HNO}_{3}+2.5 \mathrm{ml} \mathrm{HClO}_{4}$ put into the kjedahl flask, and stirred overnight. The next day, the solution was digested/heated for four hours. The solution was diluted into $50 \mathrm{ml}$ volumetric flask for overnight, and the next day the new solution/extract was measured using Atomic Absorption Spectroscopy (AAS).

The Experiment data were analyzed using combined analysis of variance across environment, and correlation analysis. Analysis of variance (ANOVA) for combined sites followed method described by Fehr [24]. The differences between genotypes were analyzed using Least Significant Different with $\alpha=5 \%$. All statistical procedure were analyzed using STAR 2.0.1 and SAS 9.4 software.

Table 1. Genetic materials for iron toxicity screening in Telang Lago, Sukamandi, and Green House. Wet Season of 2016.

\begin{tabular}{cccccc}
\hline No & Genotype & Agroecosystem & No & Genotype & Agroecosystem \\
\hline 1 & Siam Mutiara & Local variety & 11 & Inpara 1 & Swampy area \\
2 & Siam Unus & Local variety & 12 & Inpara 2 & Swampy area \\
3 & Mahsuri & Introduction variety & 13 & Inpara 3 & Swampy area \\
4 & (tolerant check) & Irrigated & 14 & Inpara 4 & Swampy area \\
5 & Ciherang & Irrigated & 15 & Inpara 5 & Swampy area \\
6 & Cilamaya Muncul & Irrigated & 16 & Inpara 6 & Swampy area \\
7 & Pokkali & Introduction variety & 17 & Inpara 7 & Swampy area \\
8 & IR 64 & Irrigated (sensitive check) & 18 & Inpara 8 & Swampy area \\
9 & Siak Raya & Swampy area & 19 & Inpara 9 & Swampy area \\
10 & Inpari 30 & Irrigated & 20 & Awan Kuning & Local variety \\
\hline
\end{tabular}

\section{Result and discussion}

\subsection{Iron content and iron uptake}

Iron content in shoot and root at the Yoshida Agar Solution was higher than in the stressed field condition (Banyuasin). Nevertheless, the iron uptake on Yoshida Agar Solution was lower than field stress condition (Figure 1). IR64 is the lowest iron content in the root compared to others genotypes, which mean iron did not accumulate in the root. While Cilamaya Muncul was the highest iron content in the shoot which mean iron was transported from the root to the shoot. All genotypes show similar response of iron content and iron uptake. Iron content mean that total iron identified in the plant organ, while iron uptake means only ferrous iron $\left(\mathrm{Fe}^{2+}\right)$ that identified in the plant organ which mean that in can be transportable. The screening of iron toxicity using Yoshida Agar Solution was effective to bind iron oxidation. Screening in seedling stage is effective and efficient for breeders to select very large early generation breeding materials [18]. This method does not require large of area, because selection for early generations have not yet consider on yield character. Therefore, in the next advanced generation of breeding materials need to be confirm its tolerance based on Yield Trials in iron-stress area. The result showed that iron content in the root were higher than the shoot in both green house and field. This result was similar to those reported that one of adaptive mechanism was aim to exclude iron into shoot and hold it in rhizosphere through capability of roots oxidizing iron before being absorbed $[8,10,23,25,26]$. 


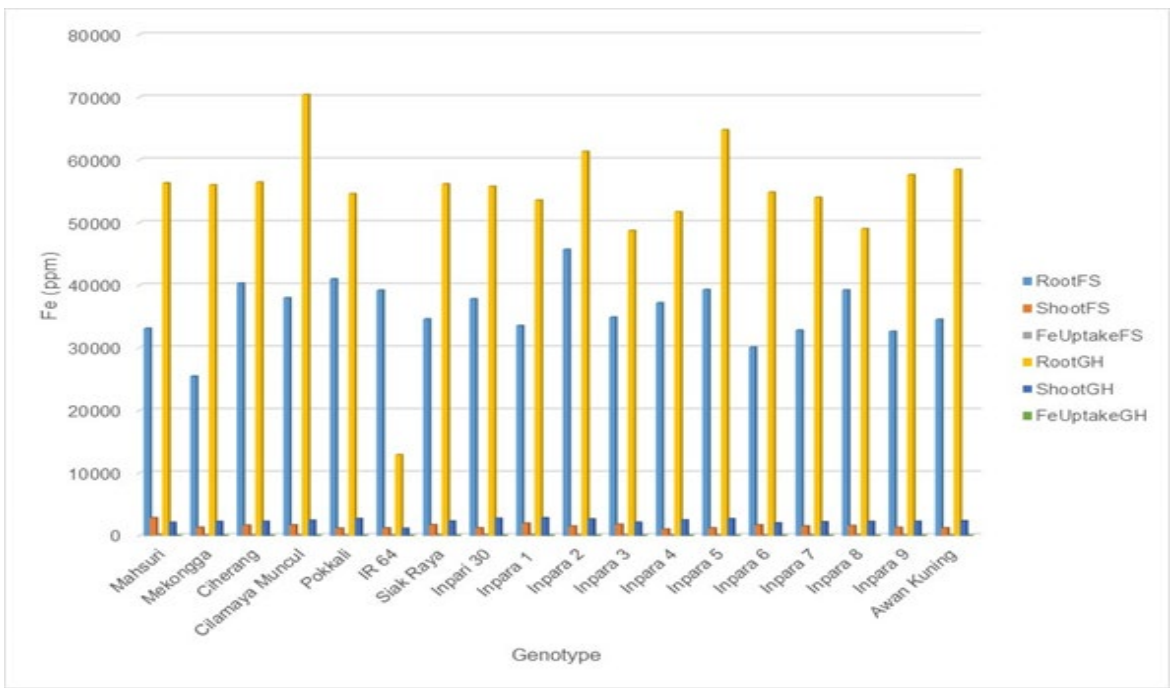

Fig. 1. Iron uptake and iron content in root and shoot. FS; Field stress = Banyuasin, GH; Green House (Yoshida Agar Solution).

The ANOVA in field condition showed that the effect of genotype was an insignificant different on iron content in root and shoot, but it was significantly different in iron uptake. All genotypes showed the presence of iron content resulted an insignificantly difference between tolerant and sensitive genotypes, or inclusion mechanism was predominantly working in response iron toxicity based on iron uptake (Table 2).

Table 2. Iron uptake and iron content in root and shoot under field condition. Banyuasin, WS of 2016

\begin{tabular}{cccccc}
\hline \multirow{2}{*}{ No } & \multirow{2}{*}{ Genotype } & \multicolumn{2}{c}{ Iron content $\mathbf{( p p m )}$} & Iron uptake & \multirow{2}{*}{ LBS } \\
\cline { 2 - 3 } & Root & Shoot & 1.918 & 150 & 5 \\
\hline 1 & Siam Mutiara & 35.474 & 1.432 & 82 & 1 \\
2 & Siam Unus & 42.757 & 2.843 & 169 & 5 \\
3 & Mahsuri & 33.083 & 1.306 & 77 & 3 \\
4 & Mekongga & 25.444 & 1.653 & 70 & 5 \\
5 & Ciherang & 40.290 & 1.678 & 90 & 3 \\
6 & Cilamaya Muncul & 37.949 & 1.169 & 68 & 5 \\
7 & Pokkali & 40.976 & 1.200 & 58 & 3 \\
8 & IR 64 & 39.162 & 1.722 & 128 & 5 \\
9 & Siak Raya & 34.583 & 1.223 & 146 & 7 \\
10 & Inpari 30 & 37.788 & 1.978 & 147 & 5 \\
11 & Inpara 1 & 33.515 & 1.504 & 97 & 5 \\
12 & Inpara 2 & 45.699 & 1.796 & 127 & 5 \\
13 & Inpara 3 & 34.863 & 1.022 & 69 & 5 \\
14 & Inpara 4 & 37.169 & 1.215 & 63 & 5 \\
15 & Inpara 5 & 39.268 & 1.680 & 73 & 5 \\
16 & Inpara 6 & 30.073 & 1.519 & 92 & 3 \\
17 & Inpara 7 & 32.778 & 1.578 & 147 & 5 \\
18 & Inpara 8 & 39.213 & 1.281 & 87 & 3 \\
19 & Inpara 9 & 32.600 & 1.222 & 91 & 3 \\
20 & Awan Kuning & 34.528 & ns & 73 & \\
\hline
\end{tabular}

Note: 1: tolerant, 3: moderate tolerant, 5: (moderate sensitive), 7: sensitive, 9: very sensitive 
Mahsuri as a tolerant check was the highest iron content in shoot compared to others, and although it was considered as moderate sensitive (score 5 of LBS). Siam Unus and Cilamaya Muncul has a relatively high iron content in root and a lower LBS score than Mahsuri. INPARI 30 had lower iron content, but it had higher LBS (sensitive), which mean that the cell was decay because of iron excess. However, it has been reported that in some case of rice genotypes, iron content in plant tissue was not always correlated with symptom scores [8]. This shows the difference between visual symptom and Fe concentration in leaves, hence forward it can be distinguished whether genotypes adaptive to excess of iron condition due to avoidance or accumulation of Fe in leaves.

Iron content and iron uptake in the Yoshida Agar Solution were insignificant different among genotypes. However, IR 64 (sensitive check) had a relatively lower iron content and iron uptake than others. Cilamaya Muncul had relatively high in iron content, but its iron uptake was relatively lower than others. Leaf bronzing symptom of Cilamaya Muncul was also the lowest, even the scale showed no symptom at 10 days after stress. This result was similar to the field stress condition, where Cilamaya Muncul had iron content relatively higher but lower in LBS score (Table 3). Based on the iron content and LBS score, Cilamaya could be classified as includer tolerant, which means that the genotype can tolerate to iron into shoot tissue by detoxifying enzymatically effect of iron toxicity.

Table 3. Iron uptake and iron content in root and shoot under Yoshida Agar Solution. Green house WS of 2016

\begin{tabular}{lcccccc}
\hline \multirow{2}{*}{ No } & Genotype & \multicolumn{2}{c}{ Iron content $(\mathbf{p p m})$} & Iron uptake & \multicolumn{2}{c}{ LBS } \\
& & Root & Shoot & $(\mathbf{p p m})$ & 10 DAS & 17 DAS \\
\hline 1 & Siam Salaka & 114.002 & 3.317 & 3.53 & 3 & 5 \\
2 & Siam Unus & 113.806 & 3.670 & 2.92 & 3 & 7 \\
3 & Mahsuri & 110.326 & 3.763 & 3.20 & 3 & 7 \\
4 & Mekongga & 106.852 & 3.899 & 4.39 & 5 & 7 \\
5 & Ciherang & 110.879 & 3.800 & 3.57 & 5 & 7 \\
6 & Cilamaya Muncul & 138.315 & 4.472 & 0.48 & 0 & 5 \\
7 & Pokkali & 107.171 & 4.879 & 6.68 & 3 & 7 \\
8 & IR 64 & 86.676 & 2.911 & 1.68 & 3 & 7 \\
9 & Siak Raya & 110.132 & 3.994 & 5.01 & 3 & 7 \\
10 & Inpari 30 & 109.482 & 4.543 & 4.62 & 3 & 7 \\
11 & Inpara 1 & 105.069 & 4.943 & 5.76 & 3 & 7 \\
12 & Inpara 2 & 120.636 & 4.740 & 4.62 & 3 & 9 \\
13 & Inpara 3 & 95.323 & 3.438 & 3.85 & 3 & 7 \\
14 & Inpara 4 & 101.698 & 4.523 & 5.54 & 3 & 5 \\
15 & Inpara 5 & 126.047 & 4.647 & 4.64 & 3 & 5 \\
16 & Inpara 6 & 107.632 & 3.601 & 3.67 & 3 & 5 \\
17 & Inpara 7 & 105.560 & 3.769 & 4.75 & 3 & 5 \\
18 & Inpara 8 & 96.126 & 3.863 & 6.08 & 3 & 5 \\
19 & Inpara 9 & 113.318 & 3.905 & 4.06 & 3 & 5 \\
20 & Awan Kuning & 114.576 & 4.269 & 4.31 & 3 & 5
\end{tabular}

Note: 1: tolerant, 3: moderate tolerant, 5: (moderate sensitive), 7: sensitive, 9: very sensitive

Based on LBS and Fe content in the tissues, scientist defines two types of tolerant varieties, that were the includers which have a high Fe content but low leaf bronzing and the excluders which have a low Fe content and low leaf bronzing [4]. Cilamaya Muncul and Siam Unus was identified as includer tolerant because it has high iron concentration both in plant tissue in stress condition in nutrient culture and in iron-toxicity hotspot area (Banyuasin) and showed low leaf bronzing symptom. All Inpara series (except for Inpara 2 and 3) and Awan Kuning had low LBS scores (moderate tolerant) under Yoshida Agar Solution as well as in the field conditions. Inpara 7. Inpara 8 and Awan Kuning could be assumed as excluder 
tolerant. However, it should be considered that iron content is not always correlate with tolerance level $[4,22]$. Under field stress conditions, iron content in roots was not correlated with iron content in shoot and the iron uptake. Iron content in shoot was correlated with iron uptake. Under Yoshida Agar Solution. Iron content in the roots was correlated with iron content in shoot but not correlation with iron uptake. Meanwhile, there was correlation between iron content and iron uptake (Table 4).

Table 4. Correlation between iron content and iron uptake

\begin{tabular}{ccccc}
\hline & \multicolumn{2}{c}{ Field condition } & \multicolumn{2}{c}{ Yoshida Agar Solution } \\
\cline { 2 - 5 } & Fe-Shoot & Fe-uptake & Fe-Shoot & Fe-uptake \\
\hline Fe-Root & -0.223 & -0.148 & $0.468^{*}$ & -0.305 \\
Fe-Shoot & & $0.696^{* *}$ & & $0.491^{*}$ \\
\hline
\end{tabular}

\subsection{Genotype $\mathrm{x}$ iron toxicity interaction on yield and yield component}

The response of genotype under iron toxicity in the field condition (Banyuasin) and normal condition (Sukamandi) was to compare reduction of performance under iron stressed compared to non-stressed environment, which can be used as an indicator economically judgment of tolerance genotypes [2]. According to the combined analysis of variance, the effect of stress conditions on the number of filled grain and unfilled grains, dry weight of shoot and root, yield and weight of 1000-grains were bid difference. Meanwhile, the effect of genotype was different on all observed characters. Effect of genotype $\mathrm{x}$ stress condition interaction was different on number of productive tillers, number of filled and unfilled grain, dry weight of shoot and root, weight of 1000 grain, and yield (Table 5 and 6). It means that genotypes tested have different response of reduction of yield grain, yield components, and also dry weight of shoot and root.

Table 5. Anova of plant height, number of productive tillers, number of filled and unfilled grains of rice genotype under stress and normal condition

\begin{tabular}{|c|c|c|c|c|c|c|c|c|c|}
\hline \multirow{2}{*}{$\begin{array}{l}\text { Source of } \\
\text { variance }\end{array}$} & \multirow[t]{2}{*}{ DF } & \multicolumn{2}{|c|}{ Plant height } & \multicolumn{2}{|c|}{$\begin{array}{c}\text { No. of productive } \\
\text { tillers }\end{array}$} & \multicolumn{2}{|c|}{ No. of filled grain } & \multicolumn{2}{|c|}{ No. of unfilled grain } \\
\hline & & MS & $\operatorname{Pr}(>$ F $)$ & MS & $\operatorname{Pr}(>\mathbf{F})$ & MS & $\operatorname{Pr}(>$ F $)$ & MS & $\operatorname{Pr}(>\mathbf{F})$ \\
\hline Site & 1 & 1959.26 & 0.155 & 194.68 & 0.276 & 5320.04 & 0.01 & 30737.81 & 0.00 \\
\hline Rep/site & 4 & 639.54 & 0.007 & 122.24 & 0.000 & 215.21 & 0.69 & 128.91 & 0.73 \\
\hline Genotype & 17 & 644.91 & 0.000 & 31.06 & 0.000 & 885.67 & 0.01 & 1445.37 & 0.00 \\
\hline Genotype $\mathrm{x}$ site & 17 & 143.20 & 0.608 & 32.56 & 0.000 & 702.12 & 0.04 & 550.50 & 0.01 \\
\hline Pooled Error & 68 & 164.25 & & 8.38 & & 380.71 & & 252.32 & \\
\hline Total & 107 & & & & & & & & \\
\hline
\end{tabular}

Table 6. Anova of plant height, dry weight of shoot and root, yield and weight of 1000 grains of rice genotype under stress and normal condition

\begin{tabular}{|c|c|c|c|c|c|c|c|c|c|}
\hline \multirow{2}{*}{$\begin{array}{l}\text { Source of } \\
\text { variance }\end{array}$} & \multirow{2}{*}{ DF } & \multicolumn{2}{|c|}{ Dry weight of shoot } & \multicolumn{2}{|c|}{ Dry weight of root } & \multicolumn{2}{|c|}{ Yield } & \multicolumn{2}{|c|}{ Weight of 1000 grains } \\
\hline & & MS & $\operatorname{Pr}(>F)$ & MS & $\operatorname{Pr}(>\mathbf{F})$ & MS & $\operatorname{Pr}(>\mathbf{F})$ & MS & $\operatorname{Pr}(>F)$ \\
\hline Site & 1 & 134323.68 & 0.00 & 3238.46 & 0.01 & 34.96 & 0.04 & 86.05 & 0.03 \\
\hline Rep/site & 4 & 1561.95 & 0.01 & 155.74 & 0.04 & 3.61 & 0.00 & 7.18 & 0.03 \\
\hline Genotype & 17 & 949.33 & 0.02 & 158.38 & 0.00 & 3.02 & 0.00 & 21.09 & 0.00 \\
\hline Genotype $\mathrm{x}$ site & 17 & 1001.06 & 0.01 & 122.10 & 0.02 & 2.12 & 0.00 & 24.45 & 0.00 \\
\hline Pooled Error & 68 & 451.45 & & 59.72 & & 0.61 & & 2.45 & \\
\hline Total & 107 & & & & & & & & \\
\hline
\end{tabular}

Response of plant height under iron toxicity and optimal conditions was scanty varied, although the interaction of genotype $\mathrm{x}$ stress condition was insignificant (Table 6). This variation may be low so it could not arise interaction. The number of productive tillers of 
genotypes varies from normal to stress condition. Not all genotypes had decreased in the number of tillers under stressed condition while all genotypes decreased in dry weight of shoot and root from normal to stress. The average of number of grains per panicle in normal condition was relatively less than the in stress condition. This might be caused severely attacked by bacterial leaf blight and smell bug (Leptocorisa oratorius) during grain filling. However, the weight of 1000 and dry weight of shoot and root of normal condition was higher compared to stress conditions which also contributed to the grain yield (Table 7).

Table 7. Plant height, number of productive tillers, dry weight of shoot and root of rice genotype under iron toxicity and normal condition

\begin{tabular}{|c|c|c|c|c|c|c|c|c|c|c|c|c|c|}
\hline \multirow{2}{*}{ No } & \multirow{2}{*}{ Genotype } & \multicolumn{3}{|c|}{ Plant height (cm) } & \multicolumn{3}{|c|}{ No. of tiller } & \multicolumn{3}{|c|}{ Dry weight of shoot (g) } & \multicolumn{3}{|c|}{ Dry weight of root (g) } \\
\hline & & Normal & Stress & Mean & Normal & Stress & Mean & Normal & Stress & Mean & Normal & Stress & Mean \\
\hline 1 & Siam Mutiara & 131 & 110 & 120 & 21 & 16 & 19 & 59.5 & 20.6 & 40.1 & 26.5 & 16.9 & 21.7 \\
\hline 2 & Siam Unus & 113 & 85 & 99 & 15 & 20 & 17 & 52.8 & 12.0 & 32.4 & 18.5 & 9.1 & 13.8 \\
\hline 3 & Mahsuri & 132 & 117 & 125 & 19 & 16 & 17 & 84.2 & 16.0 & 50.1 & 19.6 & 10.4 & 15.0 \\
\hline 4 & Mekongga & 107 & 97 & 102 & 17 & 16 & 16 & 68.1 & 14.6 & 41.3 & 11.3 & 8.8 & 10.0 \\
\hline 5 & Ciherang & 110 & 115 & 113 & 17 & 14 & 15 & 75.3 & 14.5 & 44.9 & 14.5 & 7.3 & 10.9 \\
\hline 6 & Cilamaya Muncul & 96 & 98 & 97 & 12 & 17 & 14 & 48.7 & 16.1 & 32.4 & 11.2 & 8.4 & 9.8 \\
\hline 7 & Pokkali & 109 & 124 & 116 & 7 & 11 & 9 & 58.1 & 16.7 & 37.4 & 11.8 & 8.3 & 10.1 \\
\hline 8 & IR 64 & 102 & 90 & 96 & 23 & 14 & 18 & 73.6 & 10.1 & 41.8 & 19.6 & 7.2 & 13.4 \\
\hline 9 & Siak Raya & 122 & 105 & 113 & 23 & 15 & 19 & 88.4 & 15.1 & 51.8 & 17.8 & 8.8 & 13.3 \\
\hline 10 & Inpari 30 & 107 & 98 & 102 & 11 & 14 & 12 & 107.3 & 11.6 & 59.4 & 24.2 & 7.7 & 15.9 \\
\hline 11 & Inpara 1 & 97 & 93 & 95 & 12 & 16 & 14 & 59.8 & 16.8 & 38.3 & 8.8 & 7.0 & 7.9 \\
\hline 12 & Inpara 2 & 120 & 103 & 112 & 17 & 11 & 14 & 73.4 & 19.9 & 46.7 & 10.5 & 6.3 & 8.4 \\
\hline 13 & Inpara 3 & 110 & 109 & 110 & 13 & 12 & 13 & 143.9 & 14.8 & 79.4 & 40.7 & 9.0 & 24.9 \\
\hline 14 & Inpara 4 & 94 & 81 & 87 & 19 & 9 & 14 & 70.6 & 14.5 & 42.5 & 17.2 & 8.0 & 12.6 \\
\hline 15 & Inpara 5 & 111 & 107 & 109 & 16 & 12 & 14 & 77.6 & 17.0 & 47.3 & 10.8 & 8.5 & 9.6 \\
\hline 16 & Inpara 6 & 128 & 109 & 118 & 15 & 11 & 13 & 118.2 & 16.7 & 67.4 & 25.4 & 8.8 & 17.1 \\
\hline 17 & Inpara 7 & 107 & 107 & 107 & 14 & 16 & 15 & 74.0 & 19.5 & 46.7 & 17.9 & 10.0 & 13.9 \\
\hline 18 & Inpara 8 & 134 & 116 & 125 & 18 & 11 & 15 & 95.1 & 14.2 & 54.6 & 14.3 & 8.3 & 11.3 \\
\hline 19 & Inpara 9 & 127 & 107 & 117 & 16 & 12 & 14 & 113.2 & 16.0 & 64.6 & 24.1 & 7.0 & 15.5 \\
\hline \multirow[t]{4}{*}{20} & Awan Kuning & 117 & 102 & 110 & 19 & 12 & 16 & 120.9 & 16.5 & 68.7 & 33.8 & 11.2 & 22.5 \\
\hline & Mean & 114 & 104 & 109 & 16 & 14 & 15 & 83.1 & 15.7 & 49.4 & 18.9 & 8.8 & 13.9 \\
\hline & CV (\%) & 7 & 16 & 12 & 18 & 24 & 20 & 35 & & 41.8 & 48.3 & 31.1 & 55.8 \\
\hline & $\operatorname{LSD}(5 \%)$ & 13 & 27 & 15 & 5 & 5 & 4.7 & 48 & 0.45 & 34.6 & 15.1 & 0.4 & 12.6 \\
\hline
\end{tabular}

Grain yield under normal conditions was ranged from 1.72 to $6.02 \mathrm{t} /$ ha (Table 8 ). The plant attacked by pest and diseases during maturing. Grain yield of Inpara 6 and Inpara 9 have higher than Mahsuri. Grain yield under stress condition was ranged fron 1.71 to 2.86 $\mathrm{t} / \mathrm{ha}$. Mahsuri (tolerant check) has a yield of $2.86 \mathrm{t} / \mathrm{ha}$. Cilamaya Muncul, Inpara 9, and Awan Kuning have grain yield which not significantly different with Mahsuri.

The ability of genotypes to perform reasonably well in iron toxicity stress is paramount for stability of grain yield. The relative yield performance of genotypes in iron toxicity stressed and non-stressed environments can be used as an indicator to identify tolerant genotypes. STI is a measure of tolerance degree of genotype to stress. Genotype with a higher value is considered more tolerant. Based on the STI, the tolerant genotypes were Mahsuri, Inpata 9, and Awan Kuning. Based on STI and LBS score, Cilamaya Muncul can also be identified as tolerant genotype (Table 9). 
Table 8. Number of filled, weight of 1000 grains of rice genotype under iron toxicity and normal condition

\begin{tabular}{|c|c|c|c|c|c|c|c|}
\hline \multirow{2}{*}{ No } & \multirow[b]{2}{*}{ Genotype } & \multicolumn{3}{|c|}{ No. of filled grain } & \multicolumn{3}{|c|}{ Weight of 1000 grain (g) } \\
\hline & & Normal & Stress & Mean & Normal & Stress & Mean \\
\hline 1 & Mahsuri & 61 & 67 & 64 & 17.8 & 26.2 & 22.0 \\
\hline 2 & Mekongga & 65 & 53 & 59 & 28.8 & 24.9 & 26.9 \\
\hline 3 & Ciherang & 48 & 47 & 48 & 28.2 & 23.6 & 25.9 \\
\hline 4 & Cilamaya Muncul & 46 & 83 & 65 & 25.7 & 25.6 & 25.6 \\
\hline 5 & Pokkali & 52 & 50 & 51 & 32.8 & 27.4 & 30.1 \\
\hline 6 & IR 64 & 68 & 67 & 67 & 26.8 & 24.9 & 25.9 \\
\hline 7 & Siak Raya & 50 & 82 & 66 & 28.5 & 24.1 & 26.3 \\
\hline 8 & Inpari 30 & 56 & 40 & 48 & 28.8 & 21.4 & 25.1 \\
\hline 9 & Inpara 1 & 52 & 66 & 59 & 27.2 & 25.9 & 26.5 \\
\hline 10 & Inpara 2 & 63 & 74 & 69 & 29.5 & 24.5 & 27.0 \\
\hline 11 & Inpara 3 & 20 & 69 & 44 & 24.7 & 26.0 & 25.4 \\
\hline 12 & Inpara 4 & 25 & 91 & 58 & 21.2 & 27.6 & 24.4 \\
\hline 13 & Inpara 5 & 43 & 52 & 48 & 27.8 & 26.1 & 27.0 \\
\hline 14 & Inpara 6 & 64 & 74 & 69 & 26.2 & 23.1 & 24.6 \\
\hline 15 & Inpara 7 & 46 & 78 & 62 & 29.0 & 26.6 & 27.8 \\
\hline 16 & Inpara 8 & 80 & 94 & 87 & 30.7 & 25.0 & 27.9 \\
\hline 17 & Inpara 9 & 43 & 56 & 49 & 26.2 & 24.7 & 25.4 \\
\hline 18 & Awan Kuning & 88 & 81 & 84 & 22.6 & 22.8 & 22.7 \\
\hline & Mean & 54 & 68 & 61 & 26.8 & 25.0 & 25.9 \\
\hline & CV (\%) & 40.6 & 23.4 & 32 & 5.0 & 7.2 & 6.04 \\
\hline & $\operatorname{LSD}(5 \%)$ & 36 & 27 & 32 & 2.2 & 3.0 & 2.55 \\
\hline
\end{tabular}

Table 9. Grain yield, Stress Tolerant Index, and leaf bronzing score of rice genotype under iron toxicity and normal condition

\begin{tabular}{clccccccc}
\hline \multirow{2}{*}{ No } & \multirow{2}{*}{ Genotype } & \multicolumn{3}{c}{ Yield (t/ha) } & \multirow{2}{*}{ STI } & \multicolumn{2}{c}{ LBS- } & \multicolumn{2}{c}{ LBS-greenhouse } \\
\cline { 3 - 4 } & Normal & Stress & Mean & & field stress & I & II \\
\hline 1 & Mahsuri & 4.39 & 2.86 & 3.62 & 1.17 & 5 & 3 & 7 \\
2 & Mekongga & 2.66 & 2.42 & 2.54 & 0.61 & 3 & 5 & 7 \\
3 & Ciherang & 2.61 & 2.58 & 2.60 & 0.63 & 5 & 5 & 7 \\
4 & Cilamaya Muncul & 2.88 & 2.64 & 2.76 & 0.71 & 3 & 0 & 5 \\
5 & Pokkali & 3.25 & 2.30 & 2.78 & 0.70 & 5 & 3 & 7 \\
6 & IR 64 & 3.49 & 2.20 & 2.84 & 0.72 & 3 & 3 & 7 \\
7 & Siak Raya & 3.62 & 2.25 & 2.93 & 0.76 & 5 & 3 & 7 \\
8 & Inpari 30 & 1.72 & 1.70 & 1.71 & 0.27 & 7 & 3 & 7 \\
9 & Inpara 1 & 2.07 & 2.15 & 2.11 & 0.42 & 5 & 3 & 7 \\
10 & Inpara 2 & 3.72 & 1.61 & 2.67 & 0.56 & 5 & 3 & 9 \\
11 & Inpara 3 & 2.75 & 2.31 & 2.53 & 0.59 & 5 & 3 & 7 \\
12 & Inpara 4 & 2.11 & 1.72 & 1.91 & 0.34 & 5 & 3 & 5 \\
13 & Inpara 5 & 1.90 & 1.67 & 1.78 & 0.30 & 5 & 3 & 5 \\
14 & Inpara 6 & 6.02 & 1.77 & 3.89 & 0.99 & 5 & 3 & 5 \\
15 & Inpara 7 & 1.88 & 1.64 & 1.76 & 0.29 & 3 & 3 & 5 \\
16 & Inpara 8 & 3.70 & 1.38 & 2.54 & 0.48 & 5 & 3 & 5 \\
17 & Inpara 9 & 5.13 & 2.63 & 3.88 & 1.26 & 3 & 3 & 5 \\
18 & Awan Kuning & 4.92 & 2.53 & 3.72 & 1.17 & 3 & 3 & 5 \\
\hline & Mean & 3.27 & 2.13 & 2.70 & & & & \\
& CV (\%) & 24.2 & 33.7 & 28.98 & & & & \\
\hline & LSD (5\%) & 1.31 & 1.24 & 1.27 & & & & \\
\hline
\end{tabular}




\section{Conclusion}

We observed that there was distinct response of the rice genotypes based on the iron content in plant tissue, leaf bronzing symptom, and stress tolerance index, Cilamaya Muncul was identified as includer tolerant genotype. Awan Kuning was identified as the excluder tolerant genotype. Other genotype tolerances (Inpara 4, Inpara 7, Inpara 8, and Inpara 9) still need to be reconfirmed the consistency of the tolerance.

\section{References}

1. W. Armstrong, S.H.F.W. Justin, P.M. Beckett, S. Lythe, Aqua Bot. 39 (1991)

2. S. Gao, K.K. Tanji, S.C. Scardaci, A.T. Chow, Soil Sci. Soc. Am. J. 66 (2002)

3. R.O. Souse, C.A. de Oliveira, Root Responses to Major Abiotic Stresses in Flooded Soils. In: de Oliveira CA., Varshney RK (ed), (Springer-Verlag Berlin Heidelberg, 2011)

4. M. Becker, F. Ash, J. Plant Nutr. Soil Sci. 168 (2005)

5. F. Asch, M. Becker, D.S. Kpongor, J. Plant Nutr. Soil Sci. 168 (2005)

6. Yamauchi, Peng, Plant and Soil 173 (1995)

7. A. Dobermann, T.H. Fairhurst, Nutrient disorders and nutrient management. (Manila (PH): The International Rice Research Institute, 2000)

8. Y. Nugraha, I.A. Rumanti, Iptek Tanaman Pangan 12, 1 (2017)

9. L. Wu, M.Y. Shhadi, G. Gregorio, E. Matthus, M. Becker, M. Frei, Rice 7, 8 (2014)

10. K. Engel, F. Asch, M. Becker, J. Plant Nutr. Soil Sci. 175 (2012)

11. T. Suhartini, M.A. Makarim, J. Penelitian Pertan. Tanam. Pang. 28 (2009)

12. A. Audebert, K.L. Sahrawat, J. Plant Nutr. 23 (2000)

13. J.F. Briat, K. Ravert, N. Amaud, C. Duc, J. Boucherez, B. Touraine, F. Cellier, F. Gaymard, Annals Bot. 105 (2010)

14. V. Majerus, P. Bertin, S. Lutts, Plant Sci. 173 (2007a)

15. V. Majerus, P. Bertin, V. Swenden, A. Fortemps, S. Lobreaux, S. Lutts, Biology Planta $51(2007 b)$

16. D.W. Utami, I.H. Somantri, J. Agro Biogen 10 (2014)

17. Y. Nugraha, D.W. Utami, I.D.A Rosdianti, S.W. Ardie, M. Ghulammahdi, H. Aswidinnoor. Markers-traits association for iron toxicity tolerance in selected Indonesian rice varieties. 17 (2), 753-763. https://doi.org/10.13057/biodiv/d170251 (2016a)

18. Y. Nugraha, Y., S.W. Ardie, M. Ghulamahdi, Suwarno, H. Aswidinnoor, Journal of Crop Science and Biotechnology 19, 1 (2016b)

19. A. Shimizu, C.Q. Guerta, G.B. Gregorio, and H. Ikehashi, Journal of Plant Nutrient 28 (2005)

20. S. Unoki, T. Sitaresmi, H. Ehara, Y. Nugraha, Jurnal Penelitian Pertanian Tanaman Pangan 4, 2 (2005)

21. Y. Nugraha, I.A. Rumanti1, A. Guswara1, S.W. Ardie, Suwarno, M. Ghulammahdi, H. Aswidinnoor, Jurnal Penelitian Pertanian Tanaman Pangan 35, 3 (2016)

22. K. Engel, F. Asch, M. Becker, J. Plant Nutr. Soil Sci. 175 (2012)

23. K. Engel, F. Asch, and M. Becker, J Plant Nutr Soil Sci. 175 (2012)

24. W.R. Fehr. Principles of cultivar development: Theory and Techniques, Volume 1. Thoery and The Technique. (Mc Graw Hill, 1991)

25. S. de Dorlodot, S. Lutts, P. Bertin, J. Plant Nutr. 28, 1 (2005)

26. J. Gao, D. Chao, H. Lin, Journal of Integrative Plant Biology 49, 6(2007) 